\title{
Blended Learning Implementation and Impact in Vocational Schools
}

\author{
Tri Handayani ${ }^{1}$, Ernita Maulida ${ }^{2}$, Lipur Sugiyanta ${ }^{3}$ \\ tri.handayani5894.th@gmail.com, ernitamaulida@unj.ac.id, lipurs@unj.ac.id
}

\begin{abstract}
:
The purpose of this study is to systematically review empirical evidence about how necessary blended learning for vocational education, the blended learning implementation in vocational schools, and the blended learning impact in vocational schools. It analyzed 32 studies concerning blended learning implementation and impact in vocational schools, published in the last five years. Employing the metaanalysis review method, the data were extracted and analyzed by descriptive analysis and concluded in the form of a percentage. This study's results stated that blended learning could be used as a vocational education system solution by adjusting technological advances. The highest implementation was in the design and management dimensions of blended learning at 39\%; It was considered the most important in adopting blended learning in vocational schools. Besides, the study of the highest impact was the increase in students' abilities and knowledge in the form of test scores, which was $42 \%$ higher than behavior and motivation's impact. Therefore, it is necessary for future research to develop blended learning in vocational schools by paying attention to the students' behavior and motivation impact.
\end{abstract}

Keywords: $\quad$ implementation, impact, blended learning, vocational schools

Abstrak: $\quad$ Penelitian ini bertujuan untuk meninjau secara sistematik bukti empiris tentang seberapa perlu blended learning bagi pendidikan vokasi, implementasi pembelajaran blended learning di sekolah vokasi serta dampak blended learning di sekolah vokasi yang terbit dalam 5 tahun terakhir, menganalisis 32 studi implementasi dan dampak blended learning di sekolah vokasi. Menggunakan metode peninjauan meta-analisis, selanjutnya data diekstraksi lalu dianalisis dengan analisis deskriptif dan disimpulkan dalam bentuk persentase. Hasil penelitian ini menyatakan, blended learning dapat dijadikan solusi dalam sistem pendidikan vokasi dengan menyesuaikan kemajuan teknologi. Implementasi paling tinggi pada dimensi desain dan manajemen blended learning sebesar 39\%, dimensi ini diangap paling penting dalam mengadopsi blended learning di sekolah vokasi. Dan studi dampak yang tertinggi ialah peningkatan kemampuan dan pengetahuan siswa berupa nilai hasil tes ujian, sebesar $42 \%$ lebih tinggi dari dampak perilaku dan motivasi. Karena itu perlu bagi penelitian selanjutnya untuk mengembangkan blended learning di sekolah vokasi dengan memberikan perhatian pada dampak perilaku dan motivasi siswa.

Kata Kunci: $\quad$ implementasi, dampak, blended learning, sekolah vokasi

\begin{tabular}{|l|l|l|l}
\hline Submitted: June 2020 & Reviewed: June 2020 & Accepted: August 2020 & Published: September 2020
\end{tabular}

\footnotetext{
1 Technology and Vocational Education, Universitas Negeri Jakarta

2Technology and Vocational Education, Universitas Negeri Jakarta

${ }^{3}$ Technology and Vocational Education, Universitas Negeri Jakarta
} 


\section{INTRODUCTION}

he presence of technology affects human's daily activities. According to Andrey Andoko, in the era of the industrial revolution 4.0, routine and daily jobs have been replaced by machines. Facing these challenges, educational institutions must be able to prepare competent human resources to compete with the world of work and will not be replaced by machines (Harususilo, 2018).

Minister of Education and Culture (Mendikbud), Nadiem Anwar Makarim, launched the Freedom to Learn (Merdeka Belajar) policy. Given the title Independent Campus (Kampus Merdeka), there are four policy adjustments in the scope of higher education. One of which is that universities are obliged to give students the right to take credits outside their campus for two semesters or the equivalent of 40 credits. Students can also take credits from other study programs on campus as much as one semester of the total semester that must be taken. The purpose of this policy is to get new experiences and find real problems in real life to be ready to enter the world of work (Prodjo, 2020). It is in line with vocational schools' aim, namely to prepare human resources that link and match with the industrial world. It is where Indonesia is currently being pursued so that vocational graduates have high competence and competitiveness by implementing the 321 curriculums: three active semesters on campus, two semesters in industry, and one final semester on campus or industry. The successful implementation of the 321 curriculums must be supported by several things: industry involvement in designing the educational framework, the existence of a dual education system, consisting of industry and campuses, the presence of national vocational education standards, and the existence of competent teaching staff and instructors (Wahyuni \& Safitri, 2018).

Vocational students, as prospective professional workers, must be equipped with digital literacy skills. The acceleration of information and communication technology (ICT) makes access to digital information easier, but the information is not always correct and valid. Further, one of the efforts to improve students' digital literacy skills is to apply a blended learning model that combines online and conventional learning models (Patmanthara \& Hidayat, 2018). This learning is growing rapidly, has been widely used since 2007, and adopted by higher education institutions (Hockly, 2018). However, some academics and administrators of higher education institutions still doubt the blended learning teaching quality, especially in vocational higher education, where most of the learning is handson and seems impossible to apply it online (Maarop \& Embi, 2016).

Many studies have revealed the potential for using blended learning, one of which is Effendi's research (2016), which asserted that the blended learning method could be used as an effective learning model in LPTK with a composition of $67 \%$ online and $33 \%$ face-to-face. As for other research, Eveline Siregar and Dedy Aswan (2019) revealed that blended learning could be used as a new innovation in teaching by utilizing Flipped Learning combined with Web Base Design and Moodle as a learning medium. In line with previous studies, research by Yick et al. (2019) in vocational courses, namely sewing courses, revealed that blended learning positively impacted students' ability to study independently.

Looking at the explanation above, there is a gap between the opinions of academics and educational administrators who doubt blended learning with research showing the blended learning success in vocational schools. Therefore, the authors are interested in systematically reviewing empirical evidence about how necessary blended learning for vocational education, the extent of blended learning implementation in vocational schools in the last five years, and blended learning impact on vocational schools published in the last five years.

\section{Blended Learning}

Blended learning was proposed by Garrison and Vaughan in Stein and Graham (2014), stating that blended learning is a student-centered, self-contained, flexible, and resource-rich approach to learning. However, this learning is only to complement face-to-face learning, and web-based learning 
alone is not considered blended learning. On the other hand, Hofmann (2018) defines Blended Learning as a series of content blocks sequenced to create a learning experience. Moreover, the most common definition of blended learning is a combination of physical learning and online learning (Mohamed-Amin et al., 2014; Liu et al., 2016; Han \& Ellis, 2019). Thus, blended learning can be defined as a teaching and learning approach that integrates web-based learning and face-to-face interactions.

Research has shown that the blended learning implementation has exhibited a sizeable positive effect on the teaching and learning process (Al IHassan \& Shukri, 2017; Dziuban et al., 2018), including its implementation in Indonesia (Surjono et al., 2017; Kristanto et al., 2017; Siregar \& Aswan, 2019). When face-to-face learning coupled with online learning is carried out, it makes student learning resources broader, and student interaction and participation increase (Al IHassan \& Shukri, 2017; Inggriyani et al., 2019). Besides, blended learning provides flexibility to the teacher and increases the time to provide feedback to students (Margolis et al., 2017; Shamad, Asfiati; Wekke, 2019). Many positive impacts of blended learning have attracted many curriculum implementers' attention to adopt a way of delivering blended learning for their institutions.

\section{Vocational School}

Vocational schools aim to prepare human resources who are ready to work by providing learning programs focused on specific careers in accordance with the chosen study program (Fuller, 2015). Furthermore, Deutscher \& Winther (2018) defines a vocational school as a forum for training students to develop students' vocational knowledge and abilities. Besides, another definition states vocational school as a forum for creating systemic integrity from the integrative interaction between education, science, and industry aimed at experts' formation who are ready for lifelong learning, capable of carrying out certain types of professional activities, self-organizing, and competitive in the labor market (Kamasheva et al., 2016). It can be affirmed that vocational school is a forum for preparing professional human resources in accordance with the vocational field.

The blended learning implementation's flexibility makes it compatible with various education system models. One of which is applied to the vocational education learning system. In Tanzania, vocational schools have started to develop blended learning in the Vocational Education and Training (VET) program, which focused on the students' and lecturers' needs (Machumu et al., 2016). On the other hand, the blended learning development was also adopted by Mohamed El Hajji et al. (2016) in Maroko, Bo Man Wong (2018) in Hongkong Institute of Vocational Education, and Muhamad Azhar Stapa \& Nazeri Mohammad (2019) in Malaysia, where the development focus is on blended learning design.

Not only that, but several vocational schools in Indonesia have also adopted blended learning by developing Vocational Blended Learning (VBL), in which the learning process applies a rotational learning model and is supported by content developed by lecturers at the Bali State Polytechnic (Dewi et al., 2018). Blended learning was also applied to the Indonesian Aviation College (Rahayu, 2017). Although many studies have revealed the positive potential of blended learning, there remains debate about the blended learning delivery for Vocational and Professional Training, as it is mostly hands-on practice and seems unlikely if applied online ( $\mathrm{Ng}$ et al., 2017).

Blended learning in vocational schools requires a good balance between theoretical lessons, online lectures, and face-to-face lectures so that online learning media are needed to present the actual situation in the classroom (Puri, 2018). There are differences in each blended learning development in vocational schools, especially in its implementation object. Apart from implementation, it turns out that the blended learning impact is also different for each student (Rajabi et al., 2017). Therefore, it is necessary to review the extent to which the blended learning's implementation and impact in vocational schools to determine what implementation and impact the previous researchers have not seen. 


\section{RESEARCH METHODS}

The researchers analyzed 32 studies concerning blended learning's impact and implementation published from January 1, 2016, to February 10, 2020. Following the methodology practice (Nabi et al., 2017), This study used a systematic review process. Initially, the researchers employed the basic word "blended learning" to search through Google Scholar. Then, to search for a broader range of keywords or search terms, "vocational school", "higher education", and "Moodle" were added. After that, titles and abstracts were filtered, and studies were included if the articles met the following criteria: (a) the article discussed blended learning in vocational high schools; (b) discussed the implementation or impact (input and output) of blended learning; (c) published peer-reviewed journal articles and/or international conferences (Nabi, Liñan, Fayolle, Krueger \& Walmsley, 2017 were included because they employed meta-analysis methods, but the reviews or research agendas were not included).

Information from the articles would be extracted by examining the articles' background characteristics. It was done to interpret general patterns, such as the most prominent journal outlets, country contexts, and graduate students. An article analysis then was carried out regarding the extent to which the blended learning implementation in vocational schools and the blended learning impact (output) on vocational schools. The meta-analysis results of the blended learning implementation and impact in vocational schools were analyzed using descriptive analysis and concluded in the form of a percentage.

\section{RESULTS AND DISCUSSION}

The sample included research in the past five years, published in national, international journals, and international conferences. Mostly published in education and technology journals (62\%) and international journals and higher education (22\%). The data analyzed came from 17 countries, dominated by Asia (12 articles, 38\%); Europe (10 articles, 31\%); US (5 articles, 16\%); followed by Africa (3 articles, $9 \%$ ); Australia (1 article, 3\%); and international comparisons (1 article, 3\%). It could be concluded that Asia has much implemented vocational education as a learning system, followed by Europe, where there were many vocational schools, especially in Germany.

Based on the data, students in this study's sample were mostly students studying vocational education. The majority of whom were undergraduate students $(56 \%)$, postgraduate students $(32 \%)$, and alumni or unspecified university students. From these findings, it could be interpreted that undergraduatelevel education was preferred, where undergraduate students are relatively young and easier to educate in preparing attitudes and mentality ready to enter the industrial world and become professional personnel.

\section{Blended Learning Implementation in Vocational Schools}

The blended learning implementation has been carried out for a long time in the education world, and the researchers shared several indicators or focuses that became challenges in preparing for blended learning, especially in vocational high schools (see Table 2). The studies were, among other things, in terms of the instructors, lecturers, or staff's readiness background in carrying out blended learning in 6 articles (26\%), from the students' background, there were 5 articles $(22 \%)$, from the technology availability or infrastructure, there were 3 articles (13\%), and most focus on systematic indicators, namely the blended learning's design and management, as many as 9 articles $(39 \%)$ in which there were learning designs and strategies. 
Table 1. Blended learning implementation in Vocational Schools

\begin{tabular}{|c|c|c|c|}
\hline Instructor/Lecturer/Staff & College student & $\begin{array}{l}\text { Facilities and } \\
\text { infrastructure }\end{array}$ & $\begin{array}{l}\text { Blended Learning } \\
\text { Design and } \\
\text { Management }\end{array}$ \\
\hline $\begin{array}{l}\text { (Maarop \& Embi, 2016); } \\
\text { (Machumu et al., 2016); } \\
\text { (Boelens et al., 2017); } \\
\text { (Nortvig et al., 2018); } \\
\text { (Han \& Ellis, 2019); } \\
\text { (Setiawan et al., 2019) }\end{array}$ & $\begin{array}{l}\text { (Machumu et al., } \\
\text { 2016); (Manwaring } \\
\text { et al., 2017); } \\
\text { (Vanslambrouck et } \\
\text { al., 2018); (Nortvig } \\
\text { et al., 2018); (Yick et } \\
\text { al., 2019) }\end{array}$ & $\begin{array}{l}\text { (Porter \& Graham, } \\
\text { 2016); (Ng et al., } \\
\text { 2017); (Nortvig et al., } \\
\text { 2018) }\end{array}$ & $\begin{array}{l}\text { (Chen \& Tat Yao, } \\
\text { 2016); (Kristanto et } \\
\text { al., 2017); (Margolis } \\
\text { et al., 2017); (Jachin } \\
\text { \& Usagawa, 2017); } \\
\text { (Charitopoulos et al., } \\
\text { 2017); (Nortvig et al., } \\
\text { 2018); (Dewi et al., } \\
\text { 2018); (Thompson et } \\
\text { al., 2019); (Kulkarni et } \\
\text { al., 2019) }\end{array}$ \\
\hline Total 6 & Total 5 & Total 3 & Total 9 \\
\hline
\end{tabular}

Basically, in adopting blended learning, schools must pay attention to teachers, staff, students, and infrastructure's readiness, which can then be made the learning designs adapted to the learning environment's needs (Wong et al., 2014). Nevertheless, based on the meta-analysis results in vocational schools, the implementation focus was different so that it could be divided into four categories. The first was the implementation that focused on the instructors/lecturers/staff preparation, where there were challenges faced by instructors/lecturers in increased workload and time dedication, lack of pedagogical and technical skills to carry out programs, and difficulties in finding the right mix of face-to-face learning and online learning. Therefore, it is necessary to conduct training for educators and staff to help instructors deal with such problems (Maarop \& Embi, 2016; Boelens et al., 2017; Han \& Ellis, 2019; Setiawan et al., 2019). In addition to the implementation focus on teachers and staff, blended learning must also pay attention to the students' needs because each student in one class has a different age, economy, and final educational background (Vanslambrouck et al., 2018). In this focus, it is hoped that with the existence of blended learning, students can take part in learning according to the learning plan, and at the end result, they can have competences according to their vocational (Manwaring et al., 2017; Yick et al., 2019). Not only that, the designed blended learning must be relevant to the students' and teachers' environment so that learning is in accordance with their readiness in carrying out blended learning (Machumu et al., 2016).

The blended learning implementation does not only look at the teachers and students' readiness; it is also essential to pay attention to the infrastructure readiness in supporting blended learning, such as the availability of adequate infrastructure, technology support, and internet networks (Porter \& Graham, 2016; $\mathrm{Ng}$ et al., 2017). Learning, which combines online and face-to-face learning, needs to adopt blended learning designs and management that have been done in other schools, especially in vocational schools. Design and management indicators are used as benchmarks for the blended learning process's success, including various learning models and strategies (Chen \& Tat Yao, 2016; Kristanto et al., 2017; Margolis et al., 2017; Dewi et al., 2018). In blended learning, media is needed to convey material to students, including Moodle (Charitopoulos et al., 2017; Jachin \& Usagawa, 2017; Kulkarni et al., 2019). The blended learning development is increasingly in demand as a learning system that adapts to technological progress; thus, new innovations are also needed not to be monotonous, one of which is cross-institutional partnerships (Thompson et al., 2019). 


\section{Blended Learning Impact or Focus in Vocational Schools}

Meta-analysis was carried out by distinguishing between studies that mostly focused on indicators of the low-level blended learning impact (usually, short-term or subjective indicators at levels 1 and 2) and the higher-level blended learning impact (usually longer at level 3). A low-level indicator of subjective or personal change was found in 3 articles (22\%), which explained how blended learning impacts student attitudes. Furthermore, the abilities and knowledge were more than other categories, namely 6 articles $(42 \%)$, where the impact included learning outcomes and digital literacy skills. On the other hand, a higher-level indicator, namely the blended learning long-term impact such as learning motivation, was only contained in 4 articles (28\%). Finally, 1 article ( $8 \%$ ) of the research results were not included in any category, where the article analyzed blended learning impact in terms of time efficiency.

Table 2. Main Impacts Types in Research Focus Studies

\begin{tabular}{llll}
\multicolumn{1}{c}{ Behavior } & \multicolumn{1}{c}{ Ability and Knowledge } & \multicolumn{1}{c}{ Motivation } & \multicolumn{1}{c}{ Other } \\
\hline (Banditvilai, 2016); (Li & (Vo et al., 2017); & (Banditvilai, 2016); & (Hajji et al., 2016) \\
et al., 2018); (Yick et & (Patmanthara \& Hidayat, & (Kintu et al., 2017); & \\
al., 2019) & 2018); (Rajabi et al., & (Vanslambrouck et & \\
& 2017); (Jachin \& & al., 2018); (Ramirez- & \\
& $\begin{array}{l}\text { Usagawa, 2017); } \\
\text { (Marchalot et al., 2018); }\end{array}$ & Arellano et al., 2018) & \\
& (Kulkarni et al., 2019) & & \\
\hline Total 3 & Total 6 & Total 4 & Total 1 \\
\hline
\end{tabular}

In each study, blended learning had a different focus with an impact on students after carrying out learning with the blended learning system. The first focus was the impact on student behavior. It was the lowest level (level 1) of the blended learning impact because it was shown by attitude (Li et al., 2018). This impact could be analyzed with the five senses and fast changes. In addition to attitudes, students could improve independent learning with the blended learning system (Banditvilai, 2016; Yick et al., 2019). Furthermore, up to level 2 from the blended learning system impact was the students' abilities and knowledge. At this level, students were required to study the material provided by the teacher so that competencies were achieved according to the learning plan. This research focus was commonly carried out because the blended learning impact was seen from the student test score results (Vo et al., 2017; Patmanthara \& Hidayat, 2018; Rajabi et al., 2017; Jachin \& Usagawa, 2017; Marchalot et al., 2018; Kulkarni et al., 2019). This ability and knowledge included short-term impacts; therefore, retest tests could be carried out to assess student competencies.

The blended learning next impact was a long-term impact (level 3). At this level, it was motivation, where students not only had intellectual intelligence but emotional intelligence. This motivation is what drives individual performance improvement. By learning to use the blended learning system, it could increase student motivation to learn (Banditvilai, 2016; Vanslambrouck et al., 2018; Ramirez-Arellano et al., 2018). Motivation to learn could also be influenced by the students' background or characteristics (Kintu et al., 2017). Another blended learning impact was time efficiency in delivering online and face-to-face subject matter (Hajji et al., 2016).

Based on the data analysis results, blended learning in vocational schools is one of the solutions for delivering learning material, where the design and management dimensions of blended learning and the impact of students' abilities and knowledge had the highest percentage among other categories. In other words, these dimensions are essential to adopt blended learning in vocational schools. It is in line with research conducted by Jachin \& Usagawa (2017) at teacher vocational schools that the learning model implementation with the blended learning system could improve higher education quality and had the potential to improve the prospective teachers' education. 
A similar study was conducted by Anne-Mette Nortvig et al. (2018) by carrying out a literature review. It was stated that in adopting blended learning, vocational high schools need to pay attention to factors: the presence of educators in online settings; interactions between students, teachers, and content; designed connections between online and offline activities and between campus-related activities and related practices. It resulted in good learning outcomes, student satisfaction, and involvement in higher education collaborations, especially in professional education.

\section{CONCLUSIONS AND RECOMMENDATIONS}

The technological development acceleration makes vocational schools need to carry out learning using technology combined with conventional learning, namely blended learning. The blended learning implementation in vocational schools in the last five years has become more extensive. The highest implementation was in the design and management dimensions of blended learning by $39 \%$. It was considered the most important in adopting blended learning in vocational schools. Then, seen from the research in the last five years, the blended learning's positive impact was numerous and varied, including the impacts of behavior, abilities and knowledge, motivation, and time efficiency. The most prominent dimension of the blended learning impact or focus in vocational schools was improving students' abilities and knowledge, namely in the form of exam test scores, amounting to $42 \%$. Nevertheless, the impact in the form of behavior and motivation was no less critical. Therefore, it is necessary for further research to develop blended learning in vocational schools by paying attention to student behavior and motivation's impact.

\section{REFERENCES}

Al IHassan, Sarah; Shukri, N. (2017). The Effect of Blended Learning in Enhancing Female Students Satisfaction in the Saudi Context. Canadian Center of Science and Education, 10(6), 190-203. https://files.eric.ed.gov/fulltext/EJ1143465.pdf

Banditvilai, C. (2016). Enhancing Students' Language Skills through Blended Learning. Electronic Journal of E-Learning. https://doi.org/10.1504//JTEL.2012.051816

Boelens, R., De Wever, B., \& Voet, M. (2017). Four key challenges to the design of blended learning: A systematic literature review. In Educational Research Review. https://doi.org/10.1016/j.edurev.2017.06.001

Charitopoulos, A., Vassiliadis, S., Rangoussi, M., \& Koulouriotis, D. (2017). E-learning and blended learning in textile engineering education: A closed feedback loop approach. IOP Conference Series: Materials Science and Engineering. https://doi.org/10.1088/1757-899X/254/22/222002

Chen, W. S., \& Tat Yao, A. Y. (2016). An Empirical Evaluation of Critical Factors Influencing Learner Satisfaction in Blended Learning: A Pilot Study. Universal Journal of Educational Research. https://doi.org/10.13189/ujer.2016.040719

Deutscher, V., \& Winther, E. (2018). Instructional sensitivity in vocational education. Learning and Instruction. https://doi.org/10.1016/j.learninstruc.2017.07.004

Dewi, K. C., Ciptayani, P. I., \& Surjono, H. D. (2018). Modeling Vocational Blended Learning Based on Digital Learning Now Framework. Turkish Online Journal of Educational Technology - TOJET.

Dziuban, Charles; Graham, Charles; Moskal, Patsy; Norberg, Anders \& Sicilia, N. (2018). Blended Learning: The New Normal and Emerging Technologies. International Journal of Educational Technology in Higher Education, 15(3). https://doi.org/https://doi.org/10.1186/s41239-017-0087-5

Effendi, Z. M. (2016). Efektifitas Blended Learning Dalam Meningkatkan Akses Belajar Di LPTK. KONASPI VIII, 1-5. https://doi.org/https://doi.org/10.31227/osf.io/sha36 
Fuller, A. (2015). Vocational Education. In International Encyclopedia of the Social \& Behavioral Sciences: Second Edition. https://doi.org/10.1016/B978-0-08-097086-8.92091-9

Hajji, M., Bouzaidi, R. D., Douzi, H., \& Khouya, E. H. (2016). New blended learning strategy based on flipped-learning for vocational work-linked training. Journal of Education and Practice.

Han, F., \& Ellis, R. A. (2019). Identifying consistent patterns of quality learning discussions in blended learning. Internet and Higher Education. https://doi.org/10.1016/j.iheduc.2018.09.002

Harususilo, Y. E. (2018, May 2). Ki Hadjar Dewantara dan "Guncangan" Pendidikan Era Industri 4.0. Kompas.Com. https://edukasi.kompas.com/read/2018/05/02/15561621/ki-hadjar-dewantara-danguncangan-pendidikan-era-industri-40

Hockly, N. (2018). Blended Learning. ELT Journal, 72(1), 97-101. https://doi.org/https://doi.org/10.1093/elt/ccx058

Hofmann, J. (2018). Blended Learning (What Works in Talent Development) (What Works). ATD Press.

Inggriyani, Feby; Hamdani, Acep; Dahlan, T. (2019). Minat Belajar Mahasiswa dengan Menggunakan Blended Learning melalui Google Classroom pada Pembelajaran Konsep Dasar Bahasa Indonesia SD. PEMBELAJAR: Jurnal IImu Pendidikan, Keguruan, Dan Pembelajaran, 3(1), 28-35. https://ojs.unm.ac.id/pembelajar/article/view/8649/pdf

Jachin, N., \& Usagawa, T. (2017). Potential Impact of Blended Learning on Teacher Education in Mongolia. Creative Education. https://doi.org/10.4236/ce.2017.89104

Kamasheva, Y. L., Goloshumova, G. S., Goloshumov, A. Y., Kashina, S. G., Pugacheva, N. B., Bolshakova, Z. M., Tulkibaeva, N. N., \& Timirov, F. F. (2016). Features of vocational education management in the region. International Review of Management and Marketing.

Kintu, M. J., Zhu, C., \& Kagambe, E. (2017). Blended learning effectiveness: the relationship between student characteristics, design features and outcomes. International Journal of Educational Technology in Higher Education. https://doi.org/10.1186/s41239-017-0043-4

Kristanto, A., Mustaji, M., \& Mariono, A. (2017). The Development of Instructional Materials E-Learning Based On Blended Learning. International Education Studies. https://doi.org/10.5539/ies.v10n7p10

Kulkarni, T. P., Toksha, B. G., Bhosle, S. P., \& Deshmukh, B. (2019). Analysing the impact of moodle and its modules on students learning, a case study in mechanical engineering. Journal of Engineering Education Transformations.

Laborda, J. G. (2014). Stein, Jared \& Graham, Charles R (2014) Essentials for blended learning Routledge (New York \& London) isbn 978-0-415-63616-2 210 pp £19.99 http://www.routledge.com/books/details/9780415636162/. British Journal of Educational Technology. https://doi.org/10.1111/bjet.12177_5

Li, J., Kay, R., \& Markovich, L. (2018). Student Attitudes Toward Blended Learning in Adult Literacy and Basic Skills College Programs | Attitudes des étudiants envers l'apprentissage mixte dans les programmes collégiaux de formation de base et alphabétisation pour adultes. Canadian Journal of Learning and Technology / La Revue Canadienne de l'apprentissage et de La Technologie. https://doi.org/10.21432/cjlt27573

Liu, Q., Peng, W., Zhang, F., Hu, R., Li, Y., \& Yan, W. (2016). The Effectiveness of Blended Learning in Health Professions: Systematic Review and Meta-Analysis. Journal of Medical Internet Research. https://doi.org/10.2196/jmir.4807

Maarop, A. H., \& Embi, M. A. (2016). Implementation of Blended Learning in Higher Learning Institutions: A Review of Literature. International Education Studies. https://doi.org/10.5539/ies.v9n3p41 
Machumu, H. J., Zhu, C., \& Sesabo, J. K. (2016). Blended Learning in the Vocational Education and Training System in Tanzania: Understanding Vocational Educators' Perceptions. International Journal of Multicultural and Multireligious Understanding. https://doi.org/10.18415/ijmmu.v3i2.46

Manwaring, K. C., Larsen, R., Graham, C. R., Henrie, C. R., \& Halverson, L. R. (2017). Investigating student engagement in blended learning settings using experience sampling and structural equation modeling. Internet and Higher Education. https://doi.org/10.1016/j.iheduc.2017.06.002

Marchalot, A., Dureuil, B., Veber, B., Fellahi, J. L., Hanouz, J. L., Dupont, H., Lorne, E., Gerard, J. L., \& Compère, V. (2018). Effectiveness of a blended learning course and flipped classroom in first year anaesthesia training. Anaesthesia Critical Care and Pain Medicine. https://doi.org/10.1016/j.accpm.2017.10.008

Margolis, A. R., Porter, A. L., \& Pitterle, M. E. (2017). Best practices for use of blended learning. American Journal of Pharmaceutical Education. https://doi.org/10.5688/ajpe81349

Mohamed-Amin, E., Norazah, M. N. \& Ebrahim, P. (2014). Overview of Blended Learning. In E. Mohamed-Amin (Ed.), Blended \& Flipped Learning: Case Studies in Malaysian HEls. Universiti Kebangsaan Malaysia.

Nabi, G., LiñáN, F., Fayolle, A., Krueger, N., \& Walmsley, A. (2017). The impact of entrepreneurship education in higher education: A systematic review and research agenda. In Academy of Management Learning and Education. https://doi.org/10.5465/amle.2015.0026

Ng, R. Y. K., Lam, R. Y. S., Ng, K. K., \& Lai, I. K. W. (2017). A study of vocational and professional education and training (VPET) students and teachers' preferred support for technology based blended learning. Proceedings - 2017 International Symposium on Educational Technology, ISET 2017. https://doi.org/10.1109/ISET.2017.66

Nortvig, A. M., Petersen, A. K., \& Balle, S. H. (2018). A literature review of the factors influencing elearning and blended learning in relation to learning outcome, student satisfaction and engagement. Electronic Journal of E-Learning.

Patmanthara, S., \& Hidayat, W. N. (2018). Improving Vocational High School Students Digital Literacy Skill through Blended Learning Model. Journal of Physics: Conference Series. https://doi.org/10.1088/1742-6596/1028/1/012076

Porter, W. W., \& Graham, C. R. (2016). Institutional drivers and barriers to faculty adoption of blended learning in higher education. British Journal of Educational Technology. https://doi.org/10.1111/bjet.12269

Prodjo, W. A. (2020, February 7). Perguruan Tinggi Bisa Terapkan Kampus Merdeka Lewat 5 Permendikbud. Kompas.Com. https://edukasi.kompas.com/read/2020/02/07/15171541/perguruantinggi-bisa-terapkan-kampus-merdeka-lewat-5-permendikbud?page=all

Puri, S. A. (2018). Pengembangan Media Pembelajaran Berbasis Blended Learning Pada Mata Kuliah Tailoring. Jurnal Tata Busana, 07(03), 8-15. https://jurnalmahasiswa.unesa.ac.id/index.php/jurnaltata-busana/article/view/25281

Rahayu, S. S. (2017). Blended Learning Simulation Based Model Development. American Journal of Educational Research, 5(11), 1114-1119. https://doi.org/10.12691/education-5-11-1

Rajabi H.A; Zandi B; Ekradi E; Shakeri M. (2017). Studying The Effect Of Teaching And Teaching Combined On Students' Learning; A Case Study Of Technical And Vocational Courses. Research In Teaching, 5(2), 69-81.

Ramirez-Arellano, A., Acosta-Gonzaga, E., Bory-Reyes, J., \& Hernández-Simón, L. M. (2018). Factors affecting student learning performance: A causal model in higher blended education. Journal of 
Computer Assisted Learning. https://doi.org/10.1111/jcal.12289

Setiawan, R., Mardapi, D., Pratama, A., \& Ramadan, S. (2019). Efektivitas blended learning dalam inovasi pendidikan era industri 4.0 pada mata kuliah teori tes klasik. Jurnal Inovasi Teknologi Pendidikan. https://doi.org/10.21831/jitp.v6i2.27259

Shamad, Asfiati; Wekke, I. (2019). Lecturers' Participation in Applying Blended Learning in Islamic Higher Education in Indonesia. Universal Journal of Educational Research, 7(12), 2604-2608. https://doi.org/10.13189/ujer.2019.071207

Siregar, E., \& Aswan, D. (2019). Development of Blended Learning for Optimization Courses in Education Technology Master Program. International Conference on Education Technology.

Stapa, M. A., \& Mohammad, N. (2019). The Use of Addie Model for Designing Blended Learning Application at Vocational Colleges in Malaysia. Asia-Pacific Journal of Information Technology \& Multimedia. https://doi.org/10.17576/apjitm-2019-0801-05

Surjono, Herman; Muhtadi, Ali; Wahyuningsih, D. (2017). The Implementation of Blended Learning in Multimedia Courses for Undergraduate Students in Indonesia. International Journal of Information $\begin{array}{llll}\text { and } \quad \text { Education 7(10), 783-786. } & \text { Technology, }\end{array}$ https://www.researchgate.net/profile/Herman_Surjono/publication/312271862_The_Implementatio n_of_Blended_Learning_in_Multimedia_Courses_for_Undergraduate_Students_in_Indonesia/link s/588b2726a6fdcc225a3420bc/The-Implementation-of-Blended-Learning-in-Multime

Thompson, K., Jowallah, R., \& Cavanagh, T. B. (2019). "Solve the Big Problems." https://doi.org/10.4018/978-1-5225-7769-0.ch002

Vanslambrouck, S., Zhu, C., Lombaerts, K., Philipsen, B., \& Tondeur, J. (2018). Students' motivation and subjective task value of participating in online and blended learning environments. Internet and Higher Education. https://doi.org/10.1016/j.iheduc.2017.09.002

Vo, H. M., Zhu, C., \& Diep, N. A. (2017). The effect of blended learning on student performance at courselevel in higher education: A meta-analysis. Studies in Educational Evaluation. https://doi.org/10.1016/j.stueduc.2017.01.002

Wahyuni \& Safitri. (2018). Analisis Faktor-Faktor yang Menentukan Keberhasilan Penerapan Kurikulum 321 pada Pendidikan Vokasi. Prosiding Seminar Nasional Pendidikan Tinggi Vokasi Indonesia. https://scholar.ui.ac.id/en/publications/analisis-faktor-faktor-yang-menentukan-keberhasilanpenerapan-kur

Wong, B. M. (2018). Vocational teachers' experiences of using an online learning platform [University of Nottingham]. http://eprints.nottingham.ac.uk/52495/

Wong, L., Tatnall, A., \& Burgess, S. (2014). A framework for investigating blended learning effectiveness. Education and Training. https://doi.org/10.1108/ET-04-2013-0049

Yick, K. lun, Yip, J., Au, S. chuen, Lai, Y. yan, \& Yu, A. (2019). Effectiveness of blended learning in the first year of fashion education. International Journal of Fashion Design, Technology and Education. https://doi.org/10.1080/17543266.2018.1546910

How to cite: Handayani, T., Maulida, E., \& Sugiyanta, L. (2020). Blended learning implementation and impact in vocational schools. Teknodika, 18 (2), 146 - 155 DOI: https://doi.org/10.20961/teknodika.v18i2.42032 